\title{
Olli Löytty
}

\section{Kenelle maa kuuluu? \\ Kansakuva Arvid Järnefeltin pamfletissa Maa kuuluu kaikille!}

Arvid Järnefeltin Maa kuuluu kaikille! Matkoiltani Laukon lakkomailla vuodelta 1907 on vahva kannanotto sen puolesta, että jokaisella työtä tekevällä ihmisellä on luonnollinen oikeus maahan ja sen antimiin. Järnefeltin sanoin "maa on ihmisten yhteinen emo, jonka utareihin jokaisella ihmisellä on syntyperäinen oikeus" (Järnefelt 1907, 4; tästedes MKK). Pamfletti ilmestyi aikalaisia kuohuttaneen torpparilakon ja sitä seuranneen joukkohäädön jälkeen. Puutteellisia työolojaan ja -ehtojaan vastaan lakkoilevat Laukon ja Tottijärven kartanoiden torpparit oli virkavallan tuella häädetty kodeistaan. Monet torpista tuhottiin, jotta asukkaat eivät pääsisi muuttamaan niihin takaisin. Asunnottomiksi jäi noin 80 perhettä, 500 ihmistä.

Järnefelt matkusti tutustumaan tilanteeseen vuoden pästä tapahtumien jälkeen ja kirjoitti näkemästään pamfletin, josta tuli melkoinen myyntimenestys. Sitä myytiin peräti 25000 kappaletta, ja se muun muassa innosti vanhasuomalaisiin lukeutuvan ”Kangasalan karhun" eli Agathon Meurmanin kirjoittamaan aiheesta samannimisen vastakirjoituksen - tosin ilman huutomerkkiä. Johonkin Järnefelt tekstillään selvästi osui. Torpparilakko ja sitä koskeva julkinen keskustelu voitaneen tulkita yhdeksi ajankohdan avaintapahtumista, sillä se toi näkyviin koko joukon yhteiskunnallisia ongelmia varsin dramaattisessa valossa. Tällöin myös käsitykset kansasta ajautuivat kriisiin (esim. Moilanen 2003, 523). 1800- ja 1900-lukujen vaihteessa kansa oli poliittisesti latautunut käsite, ja monet yhteiskunnalliset liikkeet, kuten raittius-, nuorisoseura- ja työväenliike, käyttivät sitä poliittisten pyrkimystensä perusteluissa (Liikanen 2003, 299-300).

Luen Arvid Järnefeltin kiistakirjoitusta lähtökohtanani yksinkertainen kysymys: keitä ovat nuo kaikki, joihin kirjan otsikossa viitataan? Sen sijaan, että tarkastelisin kirjaa ensisijaisesti oireena tai todisteena vuosisadan alun ajattelusta, pyrin lähestymään tuota ajattelua kirjan kautta. En siis kysy niinkään sitä, millaisessa maailmassa Maa kuuluu kaikille! ilmestyi, vaan lähestyn aihetta pohtimalla, millaista maailmaa kirja itsessään rakentaa (Ks. Löytty 2006b). Taustaksi analyysilleni käsittelen kuitenkin aluksi Järnefeltin ja hänen ajamansa tolstoilaisuuden ambivalenttia asemaa aikansa aatteellisessa ilmastossa. 


\section{0 -luvun alun monikulttuurisuus}

Kun 1900-luvun alkua katsoo nykyperspektiivistä, se peittyy helposti sisällissodan vastakkainasettelun taakse. Sisällissodan aiheuttama järkytys on muokannut esimerkiksi vuoden 1905 suurlakon jälkikuvaa uuteen uskoon (Alapuro 1997, 38). Eheää kerronnallista kaarta tavoitteleva historiantulkinta ohjaa helposti ajattelemaan, että kaikki vuosisadan alun aatteellinen kehitys olisi ollut valmistautumista sisällissodan rintamalinjojen mukaiseen kahtiajakoon, ja jos jotakin poikkeavaa tuolloin esiintyikin, se ei läpäissyt historian testiä vaan hävisi jättämättä jälkeäkään (vrt. Kalela 2000, 112-115).

Esimerkiksi Järnefeltin edustama tolstoilaisuus olisi tämän näkemyksen mukaan vain historian sivupolku, joka ei johtanut mihinkään. Juha Siltala (1999, 333) esittäk̈kin varsin yksiselitteisesti, että tolstoilaisuus oli Suomessa "historian häviäjä, joka jauhautui kansalaissodan alle". Heikki Ylikangas (1990, 329-330) puolestaan märittää tolstoilaisuuden "suuruuden hetket" Suomessa 1890-luvun lopun ja vuoden 1907 välille, ja aatteen tappion sinetöi sosialistien vaalivoitto vuonna 1907.

Kehkeytymässä olleesta kaksinapaisesta vastakkainasettelusta huolimatta voidaan esittää, että juuri 1900-luvun alun Suomi oli aatteellisesti moniarvoinen maa. Järnefelt oli näkyvänä ja kuuluvana kulttuurihahmona yksi osoitus tästä "monikulttuurisuudesta" (Niemi 2005, 13). Kirjoituksissaan hän toi suomalaiseen yhteiskunnalliseen keskusteluun "ylirajaisia" oppeja, ja etenkin tolstoilaisuus yhdistetään Suomessa juuri Järnefeltiin (Nokkala 1958). Pyyteetöntä lähimmäisenrakkautta sekä yksinkertaista, maanläheistä elämäntapaa korostanut tolstoilaisuus oli yksi vuosisadan vaihteen lukuisista aatteista, jotka eivät välttämättä löytäneet näkyvää jalansijaa Suomessa, mutta joilla oli vähintäänkin välillistä vaikutusta paitsi monien aikalaisten myös myöhempien sukupolvien ajatteluun (ks. esim. Salonius-Hatakka 2000). Tolstoilaisuuden lisäksi Suomessa innostuttiin monista muistakin aatteellisista ja poliittisista virtauksista aina teosofiasta sosialismiin, uskonnollisista ja moraalireformistisista liikkeistä utopismiin ja anarkismiin (ks. esim. Kujala 1989; Markkola 2002). Aatteellinen toimeliaisuus näkyi muun muassa kaikkialla Suomessa virinneenä yhdistys- ja julkaisutoimintana.

Tolstoilaisuus ajoi yhteiskunnallista tasa-arvoa, mutta se ei ollut missään vaiheessa varsinainen kansanliike. Se ei ollut kansanliike edes siinä mielessä, että se olisi vedonnut juuri 'kansaan', siis ei-sivistyneistöön tai rahvaaseen. Kansallahan oli 1800-luvulla viitattu toisaalta kansakunnan väestöön, suomalaisiin, toisaalta taas talonpoikaissäätyyn sivistyneistön vastakohtana (Moilanen 2003, 517; Liikanen 2003). Ylikangas luonnehtii Suomessa ilmennyttä tolstoilaisuutta herätysliikkeeksi, jonka omaksuivat "kerkeimmin muutokseen pyrkivät keskiluokkaiset voimat”. Erästä Pohjanmaalla sattunutta tapausta selostaessaan hän tulee siihen johtopäätökseen, että "tolstoilaisuus Suomessa osui aatehistoriallisesti herätysliikkeiden ja sosialismin, uskonnollisen ja yhteiskunnallisen ajattelun välimaastoon” ja että pääpaino oli kuitenkin uskonnossa. Se ei siis 
puhutellut niinkään työväestöä kuin sivistyneistöä ja keskiluokkaa. Tolstoilaisuuden keskeiset arvot olivat Ylikankaan mukaan maata viljelevän itsenäisen pienviljelijän arvoja. Pohjanmaalla tolstoilaisuuden suosiota voidaan perustella vielä säätyläiskritiikillä eli niin sanotulla herravihalla (Ylikangas 1990, 329-330).

Ylikankaan lyhyen analyysin johtopäätöksenä on, että tolstoilaisuus ei kasvanut vain johtomiestensä persoonista, vaan tolstoilaisuus ja järnefeltiläisyys olivat "yhtä lujasti ankkuroituja ajan edellytyksiin ja ehtoihin kuin sanokaamme vaikkapa nuorisoseura-aate, radikaalifennomania, sosialismi ja myöntyväisyyssuunta”. Tolstoilaisuus sopi kuitenkin "justifiointiperustaksi” pienemmälle osalla väestöä kuin esimerkiksi fennomania. Kannatuksen laajuuden näet määräsi viime kädessä se, vastasiko tarjolla oleva aate ajan ihmisten tarpeisiin. (Ylikangas 1990, 330.) Tolstoilaisuus ei siis tukenut riittävästi aikakauden ihmisten pyrkimyksiä, jotta se olisi laajentunut varsinaiseksi kansanliikkeeksi. Toisaalta tolstoilaisuuteen kuului olennaisena perusajatuksena usko ihmisten perimmäiseen ja ylittämättömään tasavertaisuuteen, mikä mahdollisti hyvinkin radikaalit tulkinnat kansan yhteiskunnallisista oikeuksista.

\section{Kansaa jäljittelemässä}

Aatteelliset järjestöt, yhdistykset ja tolstoilaisuuden kaltaiset järjestäytymättömät liikkeet tuottivat yhteenkuuluvuudentunnetta aktiivien kesken mutta sisälsivät myös monia yhteiskuntaa kokonaisuutena koskevia ihanteita. Kansakuntaa rakennettaessa ja kuviteltaessa tarvittiin myös sopivaa yhteisöä, kansaa.

Vaikka Järnefelt oli kotoisin fennomaanikodista ja seurusteli fennomaanitaiteilijoiden kanssa, hänen paikkansa kansakunnan rakennustalkoissa ei ole aivan ongelmaton. Järnefeltiä on vaikea sijoittaa vain yhteen niistä kategorioista (säädyistä, luokista), joiden avulla vuosisadan vaihteen suomalaista yhteiskuntaa on tavattu hahmottaa. Hänestä ei oikein ole herraksi rahvasta vastaan tai sen yläpuolelle, ja jopa hänen suomalaisuutensa voidaan asettaa kyseenalaiseksi. Ensinnäkin, Järnefeltit olivat kotoisin Venäjältä, äiti Elisabet oli aatelissukua Baltian Liivinmaalta ja taustaltaan suomalainen isä Alexander puolestaan Pietarin ruotsinkielisiä aatelisia. Toiseksi, Järnefelt yritti omassa filosofiassaan ja elämäntavallaan kuroa umpeen yhteiskuntaluokkien välistä kuilua. Hän muun muassa yritti opetella käsityöammatteja ja alkoi itsekin viljellä maata. Kärjistäen ilmaistuna hän oli herra, joka halusi lukeutua kernaammin "kansaan" kuin yläluokkaan.

Kirjallisuudessa tähän sivistyneistön ja rahvaan väliseen ristiriitaan etsittiin ratkaisua yhdistämällä ihanteelliseen talonpoikaan koulusivistystä ja sovittamalla näin yhteen kaupunkien säätyläiset ja maaseudun rahvas. Näin syntyneen talonpoikaisylioppilaan tunnetuin versio löytyy Järnefeltin esikoisteoksesta Isänmaa vuodelta 1893 (ks. Arminen \& Helén 1994; Lappalainen 2000, 176-177).

Koska talonpoikaisylioppilas on kahden valtahierarkian eri askelmilla sijaitsevan 
hahmon sekoitus, sitä voidaan tarkastella niin kutsutusta jälkikoloniaalisesta teoriasta tutun hybridin käsitteen avulla. Ihanteellisuudestaan huolimatta talonpojan ja ylioppilaan yhdistävä hybridi aiheuttaa epävarmuutta valtasuhteisiin jo siitä syystä, että talonpoika ei voi syntyperänsä ja taustansa takia koskaan "jäljitellä" säätyläisiä aivan oikein: talonpoikaisen kansan kannalta talonpoikaisylioppilas on valtauttava mahdollisuus, mutta sivistyneistön näkökulmasta hahmo sisältää myös yhteiskunnan järjestystä uhkaavan riskin.

Kolonialistisen diskurssin ambivalenssista kirjoittanut Homi K. Bhabha (1994) korostaa, että valtasuhde määrittää sekä vallassa olevat että ne, joihin tuota valtaa harjoitetaan. Bhabhan teoretisoima "väärin jäljittely" (mimicry) on aina epävakaata ja ristiriitaista jo siitä syystä, että kolonialistia jäljittelevä kolonisoitu on uhka valtahierarkialle (mt., 85-92). Järnefeltin tapauksessa tuo jäljittely tapahtuu kuitenkin ikään kuin nurinpäin, kun valta-asemassa oleva pyrkii jäljittelemään vallanalaisia. Hän ei siis itse ollut talonpoikaisylioppilas vaan pikemminkin "ylioppilastalonpoika", ei nousukas vaan "laskukas".

Vaikka Järnefelt kirjoittaa kansan, vallanalaisten, puolesta, hän tekee sen valta-asemansa turvin, sivistyneistön edustajana. Pyrkimyksistään ja idealistisuudestaan huolimatta hän kuuluu sivistyneistöön, jolla on Suomessa ollut puhevalta niin kansaa kuin sen tarpeita ja oikeuksia määriteltäessä. Fennomaanisen sivistyneistön edustaja Järnefelt oli sikäli, että hänenkin suhteensa "kansaan" oli ambivalentti (Moilanen 2003, 521). Sosiologi Risto Alapuron esittämää ajatusta mukaillen voikin kysyä, mikä on se paikka, johon Järnefelt asettaa itsensä kansasta puhuessaan. Lukeeko hän itsensä siihen kuuluvaksi vai tuleeko hän tahtomattaankin sijoittaneeksi itsensä sen ulkopuolelle? (Ks. Alapuro 1998, 182-183.)

Sivistyneistön jäsenenä Järnefelt kirjoitti itselleen omalla kielellään, mutta samastuessaan kansan toiminnan sisältöihin hän joutui kielellisen ongelman eteen, sillä kansan asiaa ajaessaan hän joutui operoimaan kansan kielellä. Pertti Karkama (1997, 230_ 231) toteaakin, että Järnefeltin kirjoitus oli väistämättä kaksiäänistä, dialogista. Kielellinen ja retorinen ristiriita heijastuu myös Maa kuuluu kaikille! -kirjassa rakentuvaan lukijapaikkaan. Oliko teos sittenkin osoitettu ensisijaisesti sivistyneistölle, jolla oli valta vaikuttaa yhteiskunnalliseen järjestykseen? Muodostaahan sivistysporvaristo paitsi sen ryhmän, joka katsoi itsellään olevan oikeuden puhua "yhteisistä asioista", myös yleistä mielipidettä edustavan yleisön (ks. Stenius 1999).

Sivistyneistön kansakuvan on katsottu kokeneen murroksen vuoden 1905 suurlakon jälkeen (ks. Rojola 1999, 122-132). Kansa ei totellutkaan kirjailijoiden kuvitelmia, vaan alkoi "osoittaa vaarallista kiinnostusta omaa olemistaan kohtaan" (mt., 123). Pamflettinsa perusteella Järnefeltiä onkin vaikea sijoittaa Juhani Ahon ja Eino Leinon kaltaisten kirjailijoiden joukkoon, jotka kirjoissaan purkivat pettymystään kitkerillä 
kuvauksilla niin kansasta kuin sivistyneistöstäkin. Vaikka Järnefeltin kuva kansasta oli varsin ihanteellinen ja siinä mielessä epärealistinen, hän jaksoi yhä uskoa kuvittelemansa kansan turmeltumattomuuteen ja hyvään tahtoon.

Maa kuuluu kaikille! -kirjaa voidaan lukea utopiana, ja sellaisena se on samalla vallitsevien olojen kritiikkiä (ks. Lahtinen 2002). Kirjassa kuvataan hallitsijoiden harjoittamaa väkivaltaa alamaisia kohtaan. Kysymys vallankäytöstä avaa tekstiin näkökulman, josta voisi olla mielekästä koetella jälkikoloniaalisen teorian käsitteistöä ja kysymyksenasetteluja. Miltä torpparikysymys kuulostaisi, jos sitä kutsutaan kolonialistiseksi alistamiseksi? Voidaanhan maanomistajien vallankäyttöä verrata "alkuperäisasukkaiden" oikeuksien polkemiseen.

Järnefeltin tekstin tekee tässä suhteessa mielenkiintoiseksi se, että siinä ei puhuta 'kansan' oikeuksista kansakuntaan (esim. poliittiseen päätöksentekoon) vaan paljon yleisemmällä ja varsin ihanteellisella tasolla jokaisen työtä tekevän ihmisen oikeuksista maahan - siis maahan materiaalisena hyvänä. Tässä mielessä Järnefeltin sanoma ei ole valtiollispoliittinen samalla tavoin kuin esimerkiksi Meurmanin vastapamfletin, jossa kansa märittyy varsin yksiselitteisesti kansakunnan väestöksi. Molempien pyrkimykset on kuitenkin syytä ymmärtää nimenomaan poliittisiksi, sillä sekä Järnefelt että Meurman olivat kiinnostuneita siitä, miten yhteiset asiat pitäisi hoitaa.

\section{Keskusta ja periferia}

Lajityypiltään Maa kuuluu kaikille! on pamfletti, kiistakirjoitus. Se ottaa kantaa ja pyrkii vaikuttamaan lukijoiden mielipiteisiin ja mahdollisesti myös asiaa koskeviin päätöksiin. Pamfletit ovat ideologisen taistelun välineitä (Hemánus 1974, 172, 176). Pamflettidiskurssissa on toisin sanottuna vahva suostutteleva tendenssi, ja sille on tyypillistä, että "asiasisältö koettiin muotoa tärkeämmäksi”, kuten viestinnän tutkija Pertti Hemánus asiaa luonnehtii. Vaikka Järnefeltin pamfletti osallistui ajankohtaiseen julkiseen keskusteluun, sen tyyliä voidaan pitää varsinaisia propagandistisia pamfletteja "kirjallisempana" (mt., 178; vrt. Huhtala 1981, 14-15). Juhani Niemi $(2005,173)$ vertaa Järnefelt-tutkimuksessaan Maa kuuluu kaikille! -pamfletin tyyliä aikakauden lehdistön kuvauksiin torpparien oloista ja toteaa, että ”Järnefelt lienee kaunokirjailijana dramatisoinut aikalaisilleen vielä tehokkaammin yhden ammattikunnan epäinhimillisiä olosuhteita ja saanut lukijat haukkomaan henkeään" (ks. myös Kanninen 1940, 88).

Kirjan alussa lukija viedään korkealle vuorelle katsomaan, miltä maailma näyttää lintuperspektiivistä. Alas laaksoon tähyiltäessä yksityiskohdat katoavat: "Tiedämme ainoastaan, että tämä ääretön maa ja kaikki sen loppumattomat luonnon rikkaudet ovat pienten, ihmisiksi sanottujen järkiolentojen käytettävinä’ (MKK, 4). Ylhäältä katsottuna selviää myös, ettei köyhyys voi syntyä ainakaan luonnon rikkauksien tai maan viljavuuden puutteesta. Vuoren huipulta nähtynä ei löydy selitystä, "mistä syntyy erotus 
köyhien ja rikkaiden välillä - muulla tavalla kuin että toiset tekevät työtä toiset eivät” (mts.).

Kun lukija sitten astuu kertojan taluttamana alas vuorelta, maisema tarkentuu esitykseksi sosiaalisista suhteista. Lukijalle näytetään, että maa on vain harvojen omistuksessa ja että kaiken työn tekevät ne, jotka itse eivät omista maata. Omistajat eivät edes osaisi maata viljellä, "ei ojittaa maita, tuskinpa hevosta valjastaa, vasikkaa päästää, puuta kaataa". Sen sijaan he ovat "saaneet osakseen hienoimman sivistyksen, puhuvat vieraita kieliä, matkustelevat ulkomailla, polttavat paperossia hopeisista koteloista" (MKK, 5). Viimeistään nuo hopeiset kotelot paljastavat kertojan ironisen äänensävyn; perin hyödytöntä joukkoa kaikki tyynni. Omistavan luokan elitistisestä elämäntavasta huolimatta viljelymaat ovat kuitenkin "mitä loistavimmassa kasvussa, uhkuen runsautta ja hedelmällisyyttä" (MKK, 6). Kertoja esittääkin retorisen kysymyksen:

Kuka siis nuo uhkeat, suunnattomat pellot voimassa pitää, kuka ne lannottaa, kuka ojittaa, kuka kylvää, kuka perunamaat kyntää, kuka kesannot äestää, kuka heinän niittää ja latoihin ajaa, kuka elon korjaa ja riihittää, kuka sen myllyyn vie, kuka rakennukset korjaa ja uusia pystyttää, kuka pitää tiet ja sillat voimassa, kuka se työllä ja toimella ottaa maasta sen rikkauden, jota se niin runsain määrin tarjoo? $(\mathrm{MKK}, 6)$

Suoran vastauksen sijaan kertoja kehottaa lukijaa katsomaan metsäkulmille, josta pienistä peltotilkkujen reunustamista hökkeleistä on jo ennen auringon nousua tai jopa edellisenä päivänä lähtenyt liikkeelle "keskusta kohden satoja jalkamiehiä ja naisia". Nämä ovat niitä, jotka tekevät kaikki kartanon työt vastineeksi oikeudestaan viljellä omaa pientä palstaansa. (MKK, 6.) "Lapsikin ymmärtää", opettaa Järnefelt, "ettei rikkautta ja köyhyyttä määrää työn tekeminen, vaan yksistään se, että muutamilla ihmisillä on kaikki luonnon rikkaudet hallussaan, joten heillä on käytettävänään sekä maatyöhön että tehdastyöhön nälkäpalkasta saatavaa työvoimaa” (MKK, 7).

Kirjan kertoja maalaa siis lukijan eteen kuvan maailmasta, jossa keskellä on rikas omistava luokka ja reunamilla, periferioissa, riistetyt maatyöläiset, jotka joutuvat käymään keskustassa työssä henkiriepunsa pitimiksi. Jälkikoloniaalisessa teoriassa keskustan ja periferian kaksinapaisesta suhteesta muotoutuva erilaisuuden maantiede tuottaa maailmaan järjestyksen, jossa kaikki keskuksen ulkopuolinen on jo määritelmän mukaisesti kulttuurin, vallan ja sivilisaation marginaalissa. Periferioiden saattaminen keskusten vaikutusvallan alle katsottiin kolonialistisessa ideologiassa eurooppalaisten valtakeskusten tehtäväksi, ja sen avulla perusteltiin siirtomaiden taloudellinen ja poliittinen hyötykäyttö (Ashcroft ym. 1998, 36-37). Tätä kolonialistista järjestystä Järnefelt kirjassaan kritisoi ja tekee ehdotuksia siitä, miten asiat pitäisi oikeudenmukaisesti hoitaa. Maa ei Järnefeltin mukaan saa kuulua vain niille, jotka sen syystä tai toisesta omistavat ja jotka hyötyvät muiden tekemästä työstä. 


\section{Tekstiin rakentuva lukija}

Järnefelt puhuttelee lukijaa jo ensirivillä: "Nousemme, hyvä lukija, ihmeelliselle vuorelle [--]" (MKK, 3). Kuka tuo lukija sitten on, mikä on hänen asemansa maanomistajien ja torpparien vastakkainasettelussa?

Tapa, jolla kirjassa torpparien elämää esitetään lukijalle uutena asiana, osoittaa selvästi, että teksti ei ole suunnattu ainakaan torppareille itselleen. Sen tarkoitus on vakuuttaa ne, joilla on valta päättää torpparien kohtalosta. Teksti pyrkii vaikuttamaan yleiseen mielipiteeseen, mutta kerronnan valinnat - se miten torpparien arjesta kerrotaan lukijalle - paljastavat, että lukijakunnaksi kuvitellaan nimenomaan kaupunkilainen sivistyneistö, jolla ei ole tarpeeksi tietoa maaseudun oloista. Näytettyään lukijalle lintuperspektiivistä torpparien kurjat olosuhteet kertoja viittaa "meihin", jotka nyt "voimme astua alas laaksoon ja katsella inhimillisiä oloja vähän toisilla silmillä kuin totutuilla tavallisilla" (MKK, 7). Nämä "tavalliset" silmät eivät siis ole tottuneet näkemään maaseudulla vallitsevaa epäoikeudenmukaisuutta.

Lukijakunnan rajaaminen joiksikin muiksi kuin maaseudun väestöksi käy selväksi, kun on puhe hevosten merkityksestä omistajilleen. Lukijaa puhutellaan jälleen suoraan: "Oletteko koskaan omistanut tai hoitanut hevosta, rakas lukija?" Vastaus on lyhyt ja ytimekäs: "Ette ole" (MKK, 32). Teksti on siis suunnattu kaupunkilaisille ja yleensäkin niille, jotka eivät tunne maaseutua ja siellä harjoitetun vallankäytön realiteetteja. Seikkaperäinen esitys torpparien elinolosuhteista - ja hevosten merkityksestä maatöissä - olisi tietysti tarpeeton, jos teksti olisi osoitettu torppareille itselleen. Yleinen mielipide, johon tekstillä yritetään vaikuttaa, on siis joidenkin muiden kuin torpparien asia.

Kaupunkilaisten - siis tekstin oletuslukijoiden - kuvataan olevan vieraantuneita luonnosta. Heillä on kuitenkin mahdollisuus säilyttää jonkinlainen suhde luontoon kesäisin maalle muuttaessaan. Kaupungeissa asuessaan tuota suhdetta voi Järnefeltin mukaan vaalia hankkimalla asuntoonsa "ruukkukasveja, maisemamaalauksia, häkkilintuja”, jotka pitäisivät yllä "edes muistoa heidän alkuperäisestä yhteydestänsä luonnon kanssa” (MKK, 42). Kirjoittaessaan kaupunkilaisista monikon kolmannessa persoonassa Järnefelt ei näyttäisi sijoittavan itseään samaan joukkoon. Kertoja pysyykin tekstissä ulkopuolisena tarkkailijana, puhuupa hän sitten maaseudun tai kaupungin väestöstä.

\section{Uusi Saarijärven Paavo}

Järnefeltin kuvaus särjetyistä torpista ja niiden metsissä piileskelevistä asukkaista on hyvin vaikuttavaa, eikä ole vaikea kuvitella sen saaneen lukijat haukkomaan henkeään, kuten edellä siteerattu Niemi toteaa. Pienin, sydämeenkäyvin yksityiskohdin kertoja vakuuttaa lukijaansa todistamastaan inhimillisestä hädästä. Erään torpan pihalle saapuessaan Järnefeltillä on mukanaan torpassa asuneita lapsia, jotka nostelevat maasta poliisien sinne hujan hajan heittämiä pieniä "kotikapineita". Pihalla on myös lasten 
"kotikeinu piilipuun ja seinänurkan välillä". Lapset löytävät pihalta "pikku Maijan töppösetkin, joiden punaiset nauhat olivat sateissa aivan haalistuneet" (MKK, 11).

Kertoessaan eräästä "tarmokkaasta toimenmiehestä", joka oli ryhtynyt kivimiehestä torppariksi, Järnefelt paljastaa hahmon olevan sopiva "kirjallisiin tarkotuksiinsa". Miestä Järnefelt kuvaa suoraluontoiseksi ja jyrkkäsanaiseksi ja tämän luonnetta "katajaiseksi”, eli esiin piirtyy eräänlainen kansanmiehen perikuva. Kun tämä katajaisen kansan edustaja sitten kertoo häädöstä ja kotinsa tuhoamisesta kuvaten, kuinka uunin muuri oli tuhottu ja kuinka soraa oli lentänyt taikinaan ja maitoastiaan, Järnefelt toteaa hänen olleen eniten "loukkaantunut tästä hänen vaimoansa kohdanneesta häväistyksestä”. Tämän kuultuaan kertoja parahtaa: "Mitä näen minä! Jäykkä suomalainen leuka värähtelee!" (MKK, 12-13.) Kuvatessaan tämän kansanmiehen prototyypin kohtaloa poliisien mielivallan alla, Järnefelt tulee henkilöineeksi yleisen ilmiön (tavalla, joka on tuttu myös nykypäivän tiedonvälityksestä). Taiten valittu esimerkki kuvaa tilannetta vaikuttavammin kuin mitkään tilastot tai tapahtumien ulkokohtainen kronikoiminen.

Juhani Niemen mukaan Järnefeltin pamfletissa rakentuva mallitorppari on tulkittavissa uudeksi Saarijärven Paavoksi, joka ei enää luota Herraan kuten Runebergin Paavo mutta muistuttaa sitkeydessään ja kamppailuhengessään edeltäjäänsä. Niemen mukaan Järnefelt tekee tällä sankarillaan "irtiottoa Juhani Ahon 'katajaisen kansan' passiivisista perityypeistä ja viittoo kansankuvaajana eteenpäin kohti Väinö Linnan torpparitrilogian Koskeloita ja Kivivuoria” (Niemi 2005, 175-176). Jo Paavon nimi paljastaa, että niin Järnefeltin tekstissä kuin tutkijankin jäsennyksessä kansaa edustaa ensisijaisesti miessukupuoli, ja on näin eräänlainen oletusarvo, jota ei tarvitse erikseen perustella. Kansallista esitetään nimenomaan "mallimiesten", Paavojen ja Akselien, ei niinkään Elinoiden ja muiden naishahmojen avulla (ks. Lempiäinen 2002).

Niemen esittämää torpparin kehityskaarta seuraten Järnefeltin torpparin voi tulkita murrosajan tuotteeksi, joka moniin kirjallisuudessa esiintyviin edeltäjiinsä verrattuna on itsenäistymässä ja yksilöllistymässä sekä asettumassa sääty-yhteiskunnassa vallitsevaa järjestystä vastaan. Vaikka tässä perustorpparissa hahmottuva ideaali kansasta poikkeaa aiemmista kansankuvauksista, on siinä myös jotain samaa, mikä kielen tasolla näkyy muun muassa kataja-metaforan käytössä. Järnefeltin tekstissä näkyy kuitenkin tietoisuus "katajaisuuden" aiemmasta käytöstä kansan ominaisuuksia kuvattaessa, sillä siinä pohditaan, mahtaako kataja olla edes kyllin kova puulaji, jotta torpparin luonnetta voisi siihen verrata $(\mathrm{MKK}, 13)$. Ehkä tämä uusi, modernin työtaistelun keinot omaksunut torppari on jopa sitkeämpi kuin kataja?

\section{Kansa herää unestaan}

Järnefelt kertoo lakon olevan "uusi taistelukeino, jolla sorronalainen ryhmä ihmisiä yhtaikaa keskeyttää velvollisuutensa" siihen saakka, kunnes "riidanalaiset kysymykset 
tulevat tavalla tai toisella ratkaistuiksi”. Tämän taistelukeinon torpparit olivat omaksuneet kaupunkien tehdasväestöltä, joka oli saavuttanut lakkojen avulla "suuriakin taloudellisia parannuksia”. (MKK, 28) "Armon vuonna 1905, marraskuussa", kirjoittaa Järnefelt julistavaan sävyyn, "teki koko Suomen kansa lakon, se on, lakkasi tottelemasta ylintä maallista käskijäänsä, jolle oli ikuisen uskollisuuden valan vannonut [--]" (mts. - kurs. O.L.). Suurlakon yhteydessä kansa näyttäisi viittaavan kaikkiin suomalaisiin, mutta millaisia merkityksiä kansalle annetaan torpparilakon yhteydessä?

Pamfletin ensilehdillä torppareista puhutaan neutraaliin sävyyn yleensä ihmisinä, torppareina tai työväestönä - kuin vastahakoista lukijaa suostutellen - mutta tekstin edetessä sävy muuttuu. Vastakkain asettuvat "rautakouraiset" "valtaluokat" ja "tuntoihinsa herävät kansan luokat" (MKK, 27). Kansan käsite ilmestyy tekstiin kuin varkain - lakon toisena osapuolena. Sorretut torpparit nimetään kansaksi siinä vaiheessa, kun Järnefelt alkaa ylevien periaatteellisuuksien sijaan puhua poliittisista ratkaisuista.

Selitettyään lukijalle juurta jaksain lakkoilevien torpparien esittämien vaatimusten oikeutuksen Järnefelt vetoaa siihen, että ajat ovat muuttuneet ja että "vanhoina aikoina” vallinnut yhteiskuntajärjestys on murtunut. Kansan oikeudentuntoa on loukattu: "Kansan vanha vapauden tunto on herännyt" (MKK, 37). Kansa saa tässä aivan selvästi merkityksen 'työväestö' vastakohtana 'omistavalle luokalle'. Vallanpitäjiä vasten asetettuna kansa tarkoittaa nimenomaan vallanalaisia.

Koska Järnefelt on ottanut itselleen välittäjän roolin, hän haluaa ikään kuin palauttaa maalaiskansan arvon kaupunkilaislukijan silmissä. Hän viittaa kartanonomistajiin, jotka ovat sälyttäneet kaiken ruumiillisen työn maattoman työväestön harteille ja jotka "tuskin tunnustavat olevansa samaa ihmisrotua" torppareiden kanssa. Liikarasittuneet torpparit kituvat niin henkisesti kuin ruumiillisestikin siinä määrin, että heistä on tullut "vartaloltaan vääriä" ja "epämuodostusten alaisia" (MKK, 37-38).

Tämä liikarasitus se on luonut sen kömpelön, vääräsäärisen, tylsä-ilmeisen, kaikkea käytöstapaa ja itseluottamusta vailla olevan olennon, jota kaupunkilaiset katupojat osottavat sormellaan ja sanovat "maamoukaksi". Sellaisia ei ollut kyläkunnissa asuvan kansan vanhan vapauden aikana, jonka mahtavista runotuotteista vielä nykyisetkin sukupolvet ylpeilevät. (MKK, 113.)

Kansan alennustila ei siis ole myötäsyntyistä vaan johtuu olosuhteista. Näitä olosuhteita kuvatessaan Järnefelt viittaa - jälleen kirjan tarkoitettua lukijakuntaa rajaten - kaupunkilaiseen stereotypiaan maamoukasta. Hän muistuttaa kuitenkin lukijaa kansan "runotuotteista", joista suomalaisuus on ammentanut kulttuurista identiteettiään ja joista siis kaupunkilaisetkin voivat olla ylpeitä, ja osoittaa näin tuon maamoukan olevan "vapauden aikana" eläneiden runonlaulajien perillinen. Tekstiin rakentuu kolonialistisen kuvaston mieleen tuova kaksijakoinen kuva kansasta: Järnefelt viittaa kartanonomistajien käsitykseen kansasta tuskin edes kaltaisenaan ihmisrotuna, siis eräänlaisena 
primitiivisenä alkuasukkaiden joukkona, mutta tuo sitten vastakuvaksi muinaista sivilisaatiota edustavan "jalon villin" (ks. Tarkka 1989). Torpparilakko on Järnefeltin mukaan osoitus siitä, että taloudellisen riiston myötä tylsämielisiksi taantuneet maalaiset ovat heräämässä horroksestaan ja luomassa nahkansa, joiden alta paljastuu muinaisten runonlaulajien kaltaisia vapaan kansan edustajia. Tässä karelianistisessa alkusuomalaisen ihannekuvassa on enemmän kuin ripaus rousseaulaista luonnonihmistä, jonka hahmo vilahti jo edellä Järnefeltin tulkinnoissa kaupunkilaisten katkenneesta luontoyhteydestä.

Vaikka Järnefelt puuttuukin pamfletillaan yhteiskunnalliseen epäkohtaan, hän ei esitä niinkään yhteiskunnallista reformia kuin vaatimuksen yleisten ihmisoikeuksien noudattamisesta. Oikeus maahan merkitsee oikeutta elättää itsensä työtä tekemällä. Maan yksityisomistus on Järnefeltin mukaan rikos näitä ihmisoikeuksia vastaan, ja koska laki siunaa yksityisomistuksen, se on ristiriidassa näiden perimmäisten ja luovuttamattomien ihmisoikeuksien kanssa. Lakkoilemalla, siis kieltäytymällä tekemästä vierastyötä, "kansa" puolustaa nimenomaan ihmisoikeuksiaan eikä niinkään luokka- tai muita yhteiskunnallisen järjestyksen määrittämiä oikeuksia.

\section{Meurmanin vastapamfletti}

Järnefeltin tekstiin sana "kansa" ilmestyy siis eräänlaisessa kriisitilanteessa, kun maaseudun torppariväestöstä pyritään tekemään lukijan silmissä legitiimi yhteiskunnallinen toimija. Köyhälistöstä tulee kansaa, kun se alkaa lakkoilla. Tässä suhteessa on valaisevaa katsoa, miten Järnefeltin tekstissä olennoituva kansa poikkeaa Agathon Meurmanin vastauskirjoituksen kansasta. Meurman oli sikäli luonteva kiistakumppani, että Järnefeltin tekstin voidaan ajatella olevan suunnattu nimenomaan vanhasuomalaiselle sivistyneistölle, jolla oli tuolloin valtaa päättää lainsäädännöstä.

Meurmanille kansa on ensisijaisesti jonkin maan väestö. Nimenomaan kansat, eivät jotkut yksittäiset henkilöt, ovat ensimmäisinä "täydellä todella anastaneet haltuunsa kappaleita yhteisestä maapallosta yksityiseksi omaisuudekseen" (Meurman 1908, 7). Perustelunaan Meurman käyttää Yhdysvaltojen historiaa, sillä sieltä oli kotoisin Järnefeltin pamfletissa esitetyn verouudistuksen innoittaja Henry George. Meurman nostaa esiin sen tosiasian, että Pohjois-Amerikka oli ollut kolonialistisen valloittamisen kohde: "Väittäköön H. George wain, että yksityisomaisuus maailmassa on syntynyt wäkiwallan ja juonittelujen kautta, se pitää Amerikkassa paikkansa waan siihen tapaan nähden, millä walkoiset saiwat ruskeanahkaisten maat haltuunsa." Valloittajat leikkasivat "yksityisomaisuudekseen parhaan ja raswaisimman wiipaleen maapallon Chesterjuustosta”. Englantilaiset valloittajat eivät anastaneet maata vain alkuperäisasukkailta vaan myös varhaisilta uudisasukkailta, hollantilaisilta, ranskalaisilta, ruotsalaisilta ja jopa suomalaisilta (mt., 8-9). Kun maan omistaminen merkitsee Järnefeltille kaikkien yksilöiden 
viljelyoikeutta, on maa Meurmanin mukaan ennen kaikkea kokonaisten kansojen omaisuutta ja siitä syystä lohkottu kansakuntien kokoisiksi viipaleiksi. Tätä todistaessaan hän tulee osoittaneeksi kansallisvaltioajattelun konstruktioluonteen, kuten asia nykytutkimuksessa ilmaistaisiin: "Katselkaa Amerikan Yhdyswaltojen pohjoista rajaa: suora wiiwa waltamerestä waltamereen, kukapa olisi sen woinut arwata!" Eteläinen raja on sitä vastoin muuttunut useaan kertaan aseiden voimalla (mt., 9).

Meurmanin kritiikki Järnefeltin ajattelua kohtaan kohdistuu muun muassa juuri siihen, miten tämä ymmärtää kansan. Meurman kysyy, keihin kaikkiin Järnefelt viittaa kansasta puhuessaan. Laskeeko Järnefelt mukaan "kaikki tehtaiden työmiehet, rakennusammattilaiset, y.m. ammattilaiset, kauppiaat, konttoristit j.n.e." (Meurman 1908, 10). Kysymys on kohdallinen myös tämän artikkelin kannalta, sillä se paljastaa Järnefeltin yhteiskunta-ajattelun kansaa romantisoivan luonteen. Romanttinen kansakuva oli samalla myös nostalginen, perua edelliseltä vuosisadalta, viitattiinhan 1800-luvun kirjallisuudessa kansalla usein ensisijaisesti maalaiskansaan (Lappalainen 2000, 203).

\section{Neuvottelua kansan merkityksistä}

Jos Järnefeltin torpparit ymmärretään nimenomaan kansankuvaukseksi, niin millaiseksi hän kansan kuvaa? Yhtältä tuo pamfletissa esiin piirtyvä torpparin hahmo on moniin edeltäviin kuvauksiin verrattuna itsenäisempi. Toisaalta torpparin ominaisuuksiin ei näyttäisi ainakaan kuuluvan kyky puhua puolestaan. Lakkoileminenkin vaatii selittämistä, sen tarkoitusperien kääntämistä lukevalle kaupunkilaisyleisölle. Puhemiehenä toimii kirjailija ja kulttuurivaikuttaja Järnefelt. Keneltä Järnefelt on saanut valtakirjan torppareiden puolesta puhuakseen, kysyy Meurmankin (1908, 43).

Järnefelt puhuu lähinnä ihmisistä, torppareista ja työväestä ja käyttää sanaa "kansa" painokkaasti vasta lakkoa kuvatessaan. Näistä aineksista kutoutuva käsitys kansasta oli yksi variaatio aikakauden lukuisista tavoista viitata kansaan jonkinlaisena kokonaisuutena. Se poikkesi selvästi esimerkiksi Meurmanin puheenvuoron painotuksista. Kiistakumppanit eivät voineet ymmärtää toisiaan jo siitäkään syystä, että he tarkoittivat "kansalla" niin erilaisia asioita. Tai sitten tuo erimielisyys oli tietoista pyrkimystä harjoittaa yhteiskunnallista määrittelyvaltaa.

Vaikka Järnefeltin tekstin utooppinen ulottuvuus ei kohdistu niinkään kansallisvaltion kuvitteluun kuin johonkin sitä perustavampaan ihmisyhteisön muotoon, siinä näkyy ilmestymisajan keskustelu suomalaisuudesta ja suomalaisten keskinäisistä eroista (ks. Moilanen 2003, 520-523). Yhden tapauksen perusteella ei voi tehdä yleisiä johtopäätöksiä siitä, miten kansaa määriteltiin 1900-luvun alussa. Mutta yhtäkin tekstiä tarkasti lukemalla paljastuu se, että käsitteen merkityksistä neuvoteltiin aktiivisesti ja sitä saatettiin käyttää keskenään varsin erilaisten asioiden ajamiseen. Erona aikaisempiin sivistyneistön kirjoittamiin kansankuvauksiin oli Ilkka Liikasen $(2003,3000)$ sanoin 
se, että " $[\mathrm{k}]$ ansan tahdon sisältöä ei enää voitu määritellä puhtaasti ylhäältäpäin, vaan vähintäänkin suurlakosta lähtien päähaasteena oli alhaaltapäin tulevan paikallisen kokemuksen ja tahdonmuodostuksen huomioon ottaminen”.

Siitä huolimatta, että Järnefelt kuvasi kansaa sivistyneistön aseman suomasta lintuperspektiivistä, kuvauksessa oli myös jotain uutta. Monista aikalaisistaan, kuten Juhani Ahosta, poiketen Järnefeltin katsottiinkin pamfletillaan horjuttavan vallitsevaa järjestelmää (Niemi 2005, 174). Kun järjestelmä perustui keskustan ja periferian valtahierarkiaan, Järnefeltin puhe "kaikkien" työtätekevien oikeudesta maahan oli toki vallankumouksellista tai jopa anarkistista. Järnefeltin mukaan ihminen lunasti oikeutensa maahan vain ja ainoastaan työtä tekemällä. Nostaessaan näin maaseudun työväen samalle tasolle sitä säätyhierarkiassa ylempänä olevien kanssa Järnefelt tuli myös tuottaneeksi utopian demokratiasta, jossa ihmisyys on itsessään kaiken mitta, ei esimerkiksi varallisuus, koulutus tai syntyperä.

\section{Viitteet}

${ }^{1}$ Torpparihäädöistä ja niiden määristä tarkemmin ks. Peltonen 1992, 286-300.

${ }^{2}$ Teoksen aikalaisvastaanotosta ks. Kanninen 1940, 84-88.

${ }^{3}$ Tolstoilaisuus ei järjestäytynyt yhdistyksiksi tai seuroiksi. Tolstoilaisuudesta Suomessa ja Järnefeltin merkityksestä on kirjoittanut Armo Nokkala (1958). Nokkalan tutkimus on kuitenkin varsin suppea esitys aatteen leviämisestä Suomeen (Ylikangas 1990, 322).

${ }^{4}$ Tämä artikkeli on osa Koneen Säätiön rahoittamaa tutkimushanketta, jonka nimi on "Suuri murros 1905 ja kansapuheen variaatiot". Hankkeen tarkoituksena on kartoittaa vuosisadan alun aatteellisia reunailmiöitä ja pohtia, millä kaikilla tavoin kansaa ja kansakuntaa kuviteltiin vuosisadan alussa.

${ }^{5}$ Järnefelt käsitteli ihmisten suhdetta maahan myös vuosisadan vaihteessa ilmestyneissä romaaneissaan Veljekset (1900), Helena (1902), Maaemon lapsia (1905) ja Venehojolaiset (1909). Tilitysteoksessaan Heräämiseni (1894) hän kuvaa kääntymystään tolstoilaisuuteen. ${ }^{6}$ Jälkikoloniaalisen kritiikin soveltamisesta suomalaiseen kontekstiin ks. Lehtonen \& Löytty 2007, erit. 115-116.

${ }^{7}$ Siltala (1999, 332-333) selittää Järnefeltin pyrkimystä astua työväestön joukkoon sillä, että "aatelisen kuvernöörin ja senaattorin perheessä oltiin päästy jo niin ylös yhteiskunnallisessa hierarkiassa, että pyrkyröintihuolet voitiin unohtaa ja sijaan astuivat tarvehierarkian korkeimmat tasot, itsensä toteuttaminen ja merkityksen etsintä suhteessa muihin".

${ }^{8}$ On tietysti syytä olla varovainen, kun yhdestä kontekstista peräisin olevaa teoriaa sovelletaan toiseen kontekstiin (ks. Löytty 2006a). On kysyttävä, kuinka hyvin kolonialistisia valtasuhteita analysoimaan kehitelty teoria sopii kuvaamaan suomalaista yhteiskuntaa. Toisaalta, "vaeltava teoria" (Said 1983) ja uudenlainen käsitteistö voivat parhaimmillaan purkaa luutumia, joita vallitseva historiantulkinta saattaa pitää selviöinä. Näin ajateltuna jälkikoloniaalisesta teoriasta peräisin olevat käsitteet voivat eräänlaisina heuristisina apuvälineinä auttaa näkemään esimerkiksi torpparikysymyksen uudessa valossa.

${ }^{9}$ Iso osa kirjasta on omistettu Henry Georgen ajatteluun perustuvan verouudistuksen 
esittelemiselle. Georgen opeista ks. Kanninen 1940, 31-37; Huhtala 1981, 116-120.

${ }^{10}$ Kun Järnefelt puolestaan todistelee Georgen oppien toimivuutta kertomalla eräistä myönteisistä tuloksista, joita oli saatu Uudessa Seelannissa, hän ei puutu millään tavoin siihen, että kyse on siirtomaista, joissa alkuperäisellä väestöllä ei ole minkäänlaisia oikeuksia maahansa (MKK, 62-64).

\section{Lähteet}

\section{Tutkimuskohde}

JÄRNEFELT, ARVID I 907: Maa kuuluu kaikille! Matkoiltani Laukon lakkomailla. Vihtori Kosonen, Helsinki.

\section{Tutkimuskirjallisuus}

ALAPURO, RISTO I997: Suomen älymystö Venäjän varjossa. Hanki ja jää -sarja: Helsinki: Tammi.

ALAPURO, RISTO I998: Sivistyneistön ambivalentti suomalaisuus. Teoksessa Pertti Alasuutari \& Petri Ruuska (toim.) Elävänä Euroopassa. Muuttuva suomalainen identiteetti. Tampere: Vastapaino \& Sitra, 175-189.

ARMINEN, ILKKA \& HELÉN, ILPO I994: Säädyllisyyden järjestyksestä isänmaan rakkauteen. Arvid Järnefelt ja kansallinen eetos. Tiede \& Edistys 1, 4-16.

ashCroft, bill, Griffiths, Gareth \& Tiffin, Helen i 998: Key Concepts in Post-Colonial Studies. London \& New York: Routledge

внавна, номі к. I994: The Location of Culture. London \& New York: Routledge.

HeMÁnUs, PERTTI I974: Pamflettikirjallisuus. Teoksessa Antti Eskola \& Katarina Eskola (toim.) Kirjallisuus Suomessa. Helsinki: Tammi, 168-187.

HUHTALA, LIISI I98 I: Kuu torpparin aurinko. Torppari-aihe suomalaisessa kaunokirjallisundessa 1809-1918. Helsinki: SKS.

KALELA, JORMA 2000: Historiantutkimus ja historia. Helsinki: Gaudeamus.

KANNINEn, MAUnO I940: Arvid Järnefelt maakysymyksen käsittelijänä. Henry Georgen maareformi - Järnefeltin yhteiskunnallinen maailmanparannusohjelma. Helsinki: SKS.

KARKAMA, PERTTI I997: Intellektuelli ja representaation kriisi. Näkökulma 1960-luvun kirjailijaintellektuellin ongelmiin. Teoksessa Pertti Karkama \& Hanne Koivisto (toim.) Älymystön jäljillä. Kirjoituksia suomalaisesta sivistyneistöstä ja älymystöstä. Helsinki: SKS, 214-236.

KUJALA, ANTTI 1989: Vallankumous ja kansallinen itsemääräämisoikeus. Venäjän sosiaalistiset puolueet ja suomalainen radikalismi vuosisadan alussa. Helsinki: SHS.

LAHTINEN, MiKко 2002: Matkoja mahdolliseen. Utooppisen ajattelun vaiheita. Teoksessa Mikko Lahtinen (toim.) Matkoja utopiaan. Tampere: Vastapaino, 169-247. 
LAPPALAINEN, PÄIVI 2000: Koti, kansa ja maailman tahraava lika. Näkökulmia 1880-ja 1890-luvun kirjallisuuteen. Helsinki: SKS.

LEHTONEN, MIKKO \& LÖYTTY, OLLI 2007: Suomiko toista maata? Teoksessa Joel Kuortti, Mikko Lehtonen \& Olli Löytty (toim.) Kolonialismin jäljet. Keskustat, periferiat ja Suomi. Helsinki: Gaudeamus, 105-118.

LEMPIÄINEN, KIRSTI 2002: Kansallisuuden tekeminen ja toisto. Teoksessa Tuula Gordon, Katri Komulainen \& Kirsti Lempiäinen (toim.) Suomineitonen hei! Kansallisuuden sukupuoli. Tampere: Vastapaino, 19-36.

LiIKanen, IlkKa 2003: Kansa. Teoksessa Matti Hyvärinen, Jussi Kurunmäki, Kari Palonen, Tuija Pulkkinen \& Henrik Stenius (toim.) Käsitteet liikkeessä. Suomen poliittisen kulttuurin käsitehistoria. Tampere: Vastapaino, 257-307.

LÖYTTY, OLLI 2006A: Ambomaamme. Suomalaisen lähetyskirjallisuuden me ja muut. Tampere: Vastapaino.

LÖYTTY, OLLI 2006в: Maailma kirjallisuudessa. Teoksessa Juha Herkman, Pirjo Hiidenmaa, Sanna Kivimäki \& Olli Löytty (toim.) Tutkimusten maailma. Suomalaista kulttuurintutkimusta kartoittamassa. Nykykulttuurin tutkimuskeskuksen julkaisuja 87. Jyväskylä: Jyväskylän yliopisto, 245-254.

MARKKOLA, PIRJO 2002: Synti ja siveys. Naiset, uskonto ja sosiaalinen työ Suomessa 18601920. Helsinki: SKS.

meurman, a[Gathon] I908: Maa kuuluu kaikille. Porvoo: WSOY.

MOILANEN, LAURA-KRISTIINA 2003: Myyttinen kansa. Sivstyneistön näkemysten jatkuvuudesta 1905-17. Historiallinen aikakauskirja 4, 516-531.

NIEMI, JUhani 2005: Arvid Järnefelt. Kirjailija ajassa ja ikuisuudessa. Helsinki: SKS.

nOKKala, armo I958: Tolstoilaisuus Suomessa. Aatehistoriallinen tutkimus. Helsinki: Tammi.

Peltonen, MatTi I992: Talolliset ja torpparit. Vuosisadan vaibteen maatalouskysymys Suomessa. Historiallisia tutkimuksia 164. Helsinki: SHS.

ROJOLA, LEA I999: Vastakohtien sekasortoinen maailma. Teoksessa Lea Rojola (toim.) Järkiuskosta vaistojen kapinaan. Suomen kirjallisuushistoria 2. Helsinki: SKS, 108-135. SAID, EDWARD W. I983: The World, the Text, and the Critic. Cambridge, Massachusetts: Harvard University Press.

SAlONIUS-HATAKKa, MAIJA 2000: Ei saarnaamalla vaan elämällä. Akseli ja Eelo Isohiiden tarina. Jyväskylä: Atena.

SILTALA, JUHA I999: Valkoisen äidin pojat. Siveellisyys ja sen varjot kansallisessa projektissa. Helsinki: Otava.

STENIUS, HENRIK I999: Julkisen keskustelun rajat suuriruhtinaskunnassa. Teoksessa Pertti Haapala (toim.) Talous, valta ja valtio. Tutkimuksia 1800-luvun Suomesta. Tampere: Vastapaino, 151-162. 
TARKKA, LOTTE I989: Karjalan kuvaus kansallisena retoriikkana. Ajatuksia karelianismin etnografisesta asetelmasta. Teoksessa Seppo Knuuttila \& Pekka Laaksonen (toim.) Runon ja rajan tiellä. Kalevalaseuran vuosikirja 68. Helsinki: SKS.

YLIKANGAS, HeIKKI I 990: Mennyt meissä. Suomalaisen kansanvallan historiallinen analyysi. Helsinki: WSOY. 